\section{МІГРАЦІЇ ЯК РЕСУРС У КОНТЕКСТІ \\ ІНДИВІДУАЛЬНОГО ЛЮДСЬКОГО ВИБОРУ}

\section{MIGRATION AS A RESOURCE IN THE CONTEXT INDIVIDUAL HUMAN CHOICE}

НИКИФОРЕНКО Н. О., кандидат історичних наук, доцент, завідувач кафедри соціології управління, НИКИФОРЕНКО А. Р., старший викладач кафедри гуманітарних дисциплін, Донецький державний університет управління

\author{
NYKYFORENKO N., \\ PhD in Historical Sciences, Associate \\ Professor, Head of the Department \\ of Sociology of Management, \\ NYKYFORENKO A., \\ Senior Lecturer of the Department \\ of Humanities, \\ Donetsk State University of \\ Management
}

У статті окреслюється простір можливостей, щзо його створюють міграчії для індивіда. Показано кореляиії та ефекти, притаманні системі поділу праці, в межах якої діють мігранти. Актуалізуються пізнавальні можливості вивчення мігращійної активності українщів за допомогою методології австрійської економічної школи - як діяльності у межах ринкового процесу, в логічі індивідуальної поведінки, вписаної в реаліі глобальної міграчійної взаємозалежності.

Ключові слова: міграиії; індивідуальна поведінка; наміри; дії; ринковий прочес; порівняльні переваги; сприятливі можливості; особистий вибір.

В статье очерчивается пространство возможностей, создаваемых миграчиями для индивида. Показано корреляции и эффекты, свойственные системе разделения труда, в рамках которой действуют мигранты. Актуализируются познавательные возможности изучения миграчионной активности украинщев при помощуи методологии австрийской экономической школь - как деятельности в рамках рыночного процеса, в логике индивидуального поведения, вписанного в реалии глобальной миграиионной взаимозависимости.

Ключевые слова: миграчии; индивидуальное поведение; намерения; действия; рыночный прочесс; сравнительные преимущества; благоприятные возможности; личный выбор.

The article outlines the space of opportunities created by migration for the individual. The correlations and effects inherent in the system of labor division within which migrants operate are shown. The cognitive possibilities of studying the migration activity of Ukrainians using the methodology of the Austrian School of Economics are actualized. Migration activity is viewed as an activity within the framework of the market process, in the logic of individual behavior, inscribed in the realities of global migration interdependence.

Key words: migrations, individual behavior, intentions, actions, market process, comparative advantages, favorable opportunities, personal choice. 
Постановка проблеми. Люди мають змогу вибирати, оскільки є здатними відкривати причинно-наслідкові зв'язки, які детермінують процеси змін, вишукувати нові сприятливі можливості, ставити цілі, віднаходити найпридатніші засоби для їх досягнення. Діючи у власних інтересах, люди створюють можливості вибору для інших; суспільна координація при цьому набуває рис процесу безперервного взаємного пристосування до змін в чистому зиску, що виникає в результаті їхньої взаємодії [1]. Міграції (добровільні просторові переміщення зі зміною місця проживання) $є$ природним проявом мобільності людини, обумовленим іiі прагненням до самореалізації, підвищення рівня життя, повнішого й надійнішого задоволення власних потреб та інтересів. Вони - то більш, то менш інтенсивно - відбувались упродовж усієї історії людства, не лише супроводжуючи цивілізаційний розвиток, але й подекуди визначаючи його тренди. Й якщо «історія» в цілому значною мірою $є$ саме історією міграцій, то історія останніх кількох сотень років - літописом невтомної боротьби людини за свободу пересувань, за право вільно обирати для себе місце проживання та характер діяльності - як елементів боротьби за особисту свободу та громадянські права. У XVIII-XIX ст. це була боротьба за свободу еміграції, впродовж чи не всього XX ст. - (значною мірою) за свободу імміграції, адже в привабливих для імміграції країнах було прийнято закони, що повністю заперечували їі, або жорстко обмежували [2, с. 132].

Міграційним контентом та пов'язаним 3 ним визвольними рухами й хвилями поневолення віддавна насичена й вітчизняна історія. Падіння «залізної завіси», крах комунізму, кардинальні політико-економічні зміни в Україні кінця 1980-х-початку 1990-х років принесли з собою істотне скорочення кількості адміністративних обмежень щодо проживання, пересування, набуття громадянства та виходу з нього, трудової діяльності та ділової активності наших співвітчизників, що в свою чергу, вплинуло на характер, масштаби, мотиви, географію, канали їх міграційної активності.

Міграції є реакцію людей на різницю в продуктивності праці та доходах, які генерує економіка в відповідних галузях, місцевостях, регіонах, країнах. Як частина системи розподілу праці - фундаментального соціально-економічного явища, міграції (поряд з рухом товарів та капіталу) координуються ринком за посередництвом цінових сигналів - на користь загального суспільного інтересу, шляхом постійного пристосування учасників цього руху до нової кон'юнктури, через пошук нових сприятливих можливостей та їх використання.

Аналіз останніх досліджень $i$ nублікаџій. Економічний мейнстрім розглядає міграції насамперед у контексті проблематики їх урядового регулювання, за допомогою методик макроекономічного аналізу. Вивченню міграції (насамперед - щодо впливу імміграції на країни призначення) з позицій індивідуальної свободи, в логіці поведінки homo praxios, вписаної в ринкові процеси, присвятили свої праці Л. фон Мізес $(1919,1927,1935,1944)$ - базовий інтелектуальний діяч австрійської традиції, його послідовники та інші лібертаріанці: П. Байлунд (2005, 2015), В. Блок (1998, 2011), С. Бостаф (1995), Г.-Г. Гоппе (1998, 2014), Дж. Г. Горнбергер (1995), Дж. Дейст (2018a, 2018b, 2018c, 2018d), Р. Ебелінг (1995a, 1995b), Т. Кертіс (2020), С. Кінселла (2005), М. Маккафрі (2016), Р. Макмакен (2017), Г. Мкртчян (2019), Наурастех А. (2014, 2015, 2016, 2017, 2020a, 2020b), Б. Пауелл (2010), Дж. Портес (2019), М. Ротбард 
(1994). Дж. Салерно (2017), І. Сомін (2017, 2020), М. Табелліні (2019), Ф. Н. Фернандес $(2018,2020)$.

Багато хто з вітчизняних дослідників міграції у своїх студіях, присвячених частковому випадку - міжнародній міграції українців в останнє десятиліття, за загальної теоретичної невизначеності, але з явним тяжінням до економічного націоналізму, прямо чи опосередковано заперечує переваги інтернаціоналізації ринку праці та обстоює стереотипи демографічного алярмізму. Міграція витлумачується такими дослідниками 3 позицій голізму (як певна соціальна цілісність - взаємопов'язаність одиничних актів людської поведінки межах певних множин та сукупностей, характеристики котрої є визначальними для розуміння природи зазначених актів, тобто - реальні особи-мігранти знеособлюються й розглядаються як елемент соціальної системи, динаміка останньої витлумачується як незалежна від їхніх намірів та дій, а самі наміри та дії подаються як детерміновані характером соціальної системи), есенціалізму (не як мовний конструкт, значення якого варіює у різного роду ситуативних контекстах, а під кутом зору певної сутності - 3 властивими ій незмінними якостями та властивостями), етатизму (в контексті покладання на державу завдання керівництва громадянами та турботи про них й очікування від громадян безумовної покори державі та іiі «інтересам») й внутрішнього інтервенціонізму (як об’єкт регуляторного впливу уряду, що передбачає нагляд, регулювання та контроль) й набуває вигляду болючої суспільної проблеми, що потребує невідкладного вирішення (яке мислиться в діапазоні від «міграцію зупинити», «мігрантів - повернути», до - «призупинення міграційних втрат та створення умов для зворотної міграції»); іiі наслідки окреслюються - як переважно негативні (в діапазоні від «загрозливі» до - «катастрофічні»).

Поряд із цим, за міжнародною міграцією українців вітчизняні дослідники визнають і певні «плюси»: збільшення обсягів приватних грошових переказів зза кордону й обумовлене ним розширення платоспроможного попиту вітчизняних домогосподарств (А. Гайдуцький, Б. Дмитрук та I. Чудаєва, С. Жовнір, Г. Куліков, О. Купець, П. Куцик та О. Дубовой, Р. Ластовецька, Н. Лиховід, Е. Лібанова, О. Малиновська, О. Марець, К. Ніколаєць, А. Новік, Л. Овчарова, В. Олійник та О. Фурсова, В. Обух, І. Ольшевська, В. Орєхов, О. Пікулик, Н. Побулавець, О. П'ятковська, С. Пирожков, О. Позняк, М. Руженський, Р. Стаканов, В. Стріелковскі, Г. Терещенко, В. Толуб'як, I. Уварова, К. Шиманська, [3], зниження рівня безробіття та неповної зайнятості (Т. Васильців, А. Гайдуцький, М. Когут, О. Левицька, О. Мульска, М. Ніколайчук, В. Панченко, О. Петроє та В. Васільєв, М. Руженський, Р. Стаканов), зменшення соціальної напруги в суспільстві (В. Володько, Є. Ляшенко, О. Петроє та В. Васільєв), зниження навантаження на соціальну сферу (М. Стасюк), набуття учасниками просторової мобільності нових знань та навичок, зростання кількості економічно активних й непатерналістськи налаштованих громадян (О. Ганчев та Г. Лєснікова, О. Купець, Л. Літвінчук, I. Майданік, К. Новосад, М. Яворський), зростання мобільності людського капіталу (І. Куревіна, М. Ніколайчук, О. Іванкова-Стецюк), прискорення обміну технологіями (О. Левицька, О. Мульска, Б. Юськів), збільшення можливостей для підприємництва (I. Майданік), інтернаціоналізацію освітніх процесів 
(О. Біляковська, Т. Вітряк, Т. Драгунова, О. Купець), розвиток міжкультурної компетентності, поширення серед громадян України демократичних, християнських цінностей (Н. Гумницька та М. Петруняк, І. Марков, Й. Мілян, К. Новосад, О. Стецюк-Іванкова), генерування попиту на вироблені в Україні товари в країнах перебування мігрантів, і як наслідок - зростання експортних можливостей для вітчизняних виробників (І. Піонтківська), «приток мізків» від «відтоку мізків» (К. Даннет, [4]), право ставити питання про отримання компенсації за підготовку робочої сили від країн - можливих користувачів їі трудових ресурсів, спираючись на розроблені Міжнародною організацією праці рішення (Г. Старостенко та В. Козар).

Метою статті $\epsilon$ окреслення простору можливостей, що його створюють міграції для індивіда, показ кореляцій та ефектів, притаманних системі поділу праці, в межах якої діють мігранти, актуалізація пізнавальних можливостей вивчення міграційної активності українців у системі координат, утворюваній ринковими цінами, в логіці індивідуальної поведінки, вписаної в реалії глобальної міграційної взаємозалежності.

Виклад основного матеріалу дослідження. Міжнародна міграційна активність українців вітчизняною громадською думкою сприймається надміру політизовано. Рушійними силами такої політизації (пік якої припав на період після запровадження у 2017 р. «безвізу» України з країнами СС), покликаної дезорієнтувати мільйони пересічних громадян, знецінити й зневажити їхній особистий вибір, позбавити змоги поліпшити добробут та розширити життєві перспективи, приборкати індивідуальну ініціативу та конкуренцію, підштовхнути уряд до запровадження обмежувальних заходів, i зрештою, поставити під сумнів курс України на євроінтеграцію та соціокультурну модернізацію, стали вітчизняні фінансово-олігархічні угруповання, зацікавлені в утриманні на низькому рівні видатків на заробітну платню найманих працівників, пов'язані 3 цими угрупованнями урядові та муніципальні чиновники, стурбовані несанкціонованою «згори» підприємливістю «населення», проросійські політичні сили, занепокоєні зміною вектору (зі «Сходу» на «Захід») щодо країн працевлаштування українських «заробітчан» та уможливлених цією зміною трансформаціями ментальності останніх, представники академічного середовища, занепокоєні власною незатребуваністю та небайдужі до успіхів своїх флексибільних та мобільних співвітчизників. Окремим дестабілізуючим чинником залишається значна присутність в українському інформаційному просторі російських медіа, які часто свідомо маніпулюють даними про трудову міграцію, щоб переконати споживачів у погіршенні економічної, демографічної й політичної ситуації в Україні [5].

Свобода пересування, право на вільний вибір місця проживання, характер зайнятості $\epsilon$ похідними від принципу самоприналежності особи, вперше сформульованого Джоном Локом у праці «Два трактати про врядування» (1690). Лок перетворив класичне природне право на теорію природних прав, підвалинами якої став методологічний, а отже, і політичний індивідуалізм, 3 акцентом на індивіді як одиниці дії, як суб'єкті, що мислить, відчуває, обирає та вчиняє, 3 чого випливає його концепція природного права в політиці як встановлення природних прав кожної людини [6]. Лок доводив, що людина, 
відповідно до задуму Творця, «має право вирішувати, ким їй стати і чим займатись, а також право збирати плоди власних зусиль» [цит. за: 7, с. 91].

Основи утилітаристського підходу до обгрунтування права на вільний вибір місця проживання та свободу пересування були закладені Адамом Смітом у праці «Багатство народів» (1776). У цій праці Сміт, описуючи «просту систему природної свободи» та іï переваги - спонтанний розподіл ресурсів у конкурентному середовищі з вільним ціноутворенням, висловив думку, що кожен, виходячи зі специфіки місцевих умов, може значно краще, ніж це зробив би за нього будь-хто інший - чи то який-небудь державний діяч, чи законодавець, міркувати про те, до якої саме галузі вітчизняної промисловості варто докласти власний капітал, і продукт якої саме промисловості при цьому, ймовірно, матиме найвищу цінність [цит. за: 8, с. 30].

Смітове (й фізіократів) відкриття видається цілком слушним і щодо здатності кожного 3 нас максимально продуктивно вибирати для себе місце проживання, характер зайнятості, режим мобільності, експериментуючи, ідентифікуючи порівняльні переваги (в тому значенні, яке надавав цьому поняттю Давід Рікардо), реагуючи на зміни кон'юнктури та вносячи відповідні зміни у траєкторію власної діяльності. Ця здатність обгрунтовується універсальною структурою людської логіки - можливістю визначати причину та наслідок, що дозволяє кожному 3 нас ставити власні цілі й вибирати найпридатніші засоби їх досягнення [1].

До середини XIX ст. уряди країн Європи здійснювали меркантилістську політику «накопичення населення». У подальшому більша свобода пересування працівників, усунення еміграційних бар'єрів стали наслідком поширення ліберальної політичної філософії. У XX ст. Людвіг Мізес переформулював основні принципи лібералізму, запропонувавши модернізований варіант утилітаристського обгрунтування права на вільний вибір місця проживання та свободи пересування. На думку Мізеса, «можливість для кожного 3 нас працювати й розпоряджатись заробленим там, де нам подобається, становить саму суть суспільства, заснованого на приватній власності на засоби виробництва [2, с. 132] (тобто, суспільства з ринковою економікою).

Люди вдаються до дій, виходячи з очікуваної чистої вигоди. Ці дії хоча б на короткий час змінюють відносні витрати й вигоди, пов’язані 3 тими можливостями, що відкриваються перед іншими людьми. Коли пропорція між очікуваним зиском й очікуваними витратами на будь-яку дію збільшується люди вдаються до неї частіше, якщо зменшується - рідше [9]. Як зауважує Джонатан Портес, суть економічного обгрунтування «ресурсності» міграції $\epsilon$ доволі простою: вона така ж, як і для ринків в цілому. Якщо люди приймають рішення на основі власних економічних інтересів, то максимізується ефективність, загальний обсяг виробництва й, принаймні, за певними показниками, добробут. Це стосується того, де люди живуть і працюють тією ж мірою, якщо не більше, ніж це має місце при купівлі-продажу товарів та послуг [10]. Політично ж свобода пересування, можливість обирати для себе місце для життя й роботи є однією з базових цінностей об'єднаної Свропи, однією 3 підстав створення ЄС. Для України ж, в особі піi громадян, надзвичайно важливою та специфічною є євроінтеграційна роль міграції [11]. 
Рішення щодо просторової мобільності - це вибір, основу якого складає категорія «цінності» (в значенні, яке надається цьому поняттю суб'єктивною теорією цінності). Ситуація вибору дає уявлення про систему координат, що не стільки пов'язує цілі й засоби, скільки передбачає наполегливий пошук можливостей (нових «goals and means») на підставі засвоєння досвіду минулого й напруження уяви для відкриття й розбудови майбутнього за допомогою діяльності в умовах конкуренції. Ізраель Кірцнер зауважує, що у будь-якій людській дії присутній підприємницький елемент, який дає змогу отримувати зиск в умовах невизначеності й випадковості; він важливий для економічно раціональної діяльності в цілому, проте сам не може бути проаналізованим у термінах економічно раціональної діяльності, критеріїв максимізації чи ефективності. Чисте підприємництво реалізується лише за умов відсутності від самого початку власних активів; решта ж ринкових ролей незмінно передбачають пошук сприятливих можливостей обміну наявних активів на щось більш жадане [12]. Слово «підприємництво» (у своїй латинській версії) етимологічно пов'язане з поняттями «виявляти», «бачити», «розуміти». У цьому сенсі підприємництво можна визначити як типово людську здатність бачити можливості суб'єктивного прибутку, що з'являються в навколишньому середовищі, й діяти відповідно, аби використати їх у своїх інтересах [13].

Підприємницьким духом, готовністю сприйняти реальний світ невизначеності просякнуті й міграції. Хоч абсолютна більшість мігрантів і працюють за наймом, їхнім доходам властивий високий ступінь невизначеності. Міграції потребують від їх учасників проникливості, спостережливості, пильності, готовності експериментувати, самостійності й незалежності, необхідності виносити уроки 3 власного ринкового досвіду. Неформальні «migration networks» дозволяють їх учасникам долати обмеження в економічній діяльності, еластичніше та мобільніше пристосовуватись до динаміки ринків праці/освіти (проблем, пов'язаних з інформацією та зобов'язаннями щодо умов перебування, можливостей працевлаштування/навчання, вирішення правових та побутових питань) країн призначення. Робота мігрантів стає все більш значущою рисою світової економіки та побічним продуктом глобалізації.

Багато хто 3 вітчизняних дослідників міграції, опосередковано спираючись на теорію загальної ринкової рівноваги Леона Вальраса (розширену версію теорії «рівноважного» ціноутворення Сміта-Рікардо) та перебуваючи під впливом статичного поняття економічної ефективності (в термінології Умберто де Сото), виходить 3 припущення про наявність певної збалансованості й пропорційності елементів системи суспільної взаємодії, а отже, й про брак спонук до зміни існуючого стану речей у агентів та ринків у цілому. Міграції за такого бачення набувають вигляду деструктивного чинника, який виступає джерелом різноманітних економічних, соціальних та демографічних проблем, «розхитує» («руйнує», - в шумпетеріанському слововжитку) систему суспільної взаємодії. Відновити рівновагу в ній дослідники міграції пропонують, серед іншого, за рахунок «створення на батьківщині гідних робочих місць 3 пристойними заробітками». Функціонал міграцій при цьому явно недооцінюється. Певною мірою він ототожнюється з переходом від одного стану рівноваги в системі суспільної взаємодії до іншого, зі змінами (але не 3 динамічними характеристиками процесу встановлення ринкової рівноваги), а 
сам процес - не сприймається як конкурентний (у гаєкіанському значенні цього поняття). Міграційна активність - не витлумачується як діяльність у межах ринкового процесу (тобто, в контексті постійної взаємодії рішень власників ресурсів, підприємців-виробників та споживачів), покликана перевершити зусилля інших агентів щодо задоволення запитів ринку, а дії кожного з учасників міграцій не витлумачуються як такі, що приводять у рух всю систему цін і сприяють координації й подоланню певних соціальних диспропорцій та неузгодженостей.

Міграції є актами діяльності окремих людей, отож, як суспільне явище, вони потребують пояснення саме в логіці індивідуальної поведінки - намірів та дій (тобто, людської діяльності з точки зору окремих осіб), які самі по собі погано піддаються вимірюванню й спекулятивним узагальненням в голістичних категоріях, чим грішить багато хто з вітчизняних дослідників. Пієтет до такого вимірювання, намагання за допомогою статистичних показників «зрозуміти» міграцію та прислужитись справі державного регулювання міграційних процесів $\epsilon$ рудиментом «калькуляційних» ілюзій, віри в «облік та контроль» доби соціалістичного централізованого планування [14].

Адекватна оцінка ресурсності конкретних актів просторової мобільності можлива лише в контексті відкриття та суб'єктивного сприйняття їх учасниками можливостей досягнення певних цілей чи отримання прибутку, в реалізації відповідних дій, для використання можливостей, що виникли довкола них, у системі координат, утворюваній ринковими цінами, в межах системи поділу праці та властивих їй кореляцій та ефектів. Серед останніх фундаментальне значення має закон порівняльних переваг, сформульований Д. Рікардо у праці «Принципи політичної економії та оподаткування» (1817) та розвинутий Джоном Стюартом Мілом в «Основах політичної економії» (1848). Згідно з цим законом виробничі фактори, як правило, переміщуються туди, де вони $\epsilon$ найпродуктивнішими. Тенденція до вирівнювання ставок заробітної платні за однаково цінну продуктивну працю в умовах вільного ринку коригується двома способами: або виробництво переміщується з районів з більш високою платнею до районів 3 порівняно нижчою платнею, або працівники переміщуються 3 районів $з$ порівняно нижчою платнею до районів 3 порівняно вищою платнею [15]. Закон порівняльних витрат, розроблений Рікардо для спеціальної проблеми міжнародної торгівлі, являє собою частковий випадок більш загального рікардіанського закону утворення зв'язків, згідно 3 яким міжрегіональний розподіл праці $є$ вигідним для всіх його учасників, незалежно від специфіки розміщення природних факторів виробництва, та сприяє загальному підвищенню продуктивності праці [1].

Міждержавна міграція має економічну природу, тотожню внутрішній. На думку Річарда Ебелінга, міжнародна торгівля є продовженням ідеї поділу праці всередині країни на жителів інших географічних місцин, відокремлених один від одного нанесенням політичних кордонів на карти. Зростання масштабів ринку дозволяє посилити спеціалізацію, аби скористатись різноманітними навичками та можливостями більшої кількості потенційних виробників та торговців [16], що стимулює підвищення продуктивності праці та зростання заробітної платні. Вальтер Блок підкріплює обгрунтування доцільності невимушеного руху робочої 
сили й товарів деонтологічними аргументами, зазначаючи, що «еміграція, міграція та імміграція підпадають під рубрику «злочин без жертв». Тобто жодна 3 цих трьох дій як така не порушує аксіому ненападу». Отже, міграція, пов'язана 3 перетином державних кордонів, потребує аналізу ідентично міграції, яка відбувається в межах країни [17].

Щоб скористатись сприятливою кон'юнктурою, економічно активні люди переміщуються туди, де їхній внесок $є$ найціннішим. Однією 3 порівняльних переваг мігрантів при цьому стає те, що вони, як правило, на початках готові погодитись на нижчу платню, ніж та, що існує на певному ринку праці чи гірші умови, або - на працю у «сірій» зоні. Рух робочої сили від низькопродуктивних територій (у поточних українських умовах це насамперед - сільська місцевість поза зоною впливу великих поліфункціональних міст) до високопродуктивних (в Україні перші позиції в цьому переліку посідають найбільші міста: Київ, Харків, Львів, Одеса, Дніпро) обмежує відносне перенаселення (диспропорцію між територіями щодо рівня продуктивності капіталу та робочої сили). Надлишок робочої сили чинить тиск на заробітну платню та умови праці.

На «ресурсності» міграцій з точки зору можливості для окремих виборців жити відповідно до політики, яку вони підтримують, наголошує Ілля Сомін. На його думку, можливість виходу з певної юрисдикції та входження до іншої $\epsilon$ найдешевшим інструментом поліпшення політичної й економічної свободи особи; індивідуальний добровільний розподіл шляхом міграції до різних юрисдикцій 3 різною політикою $\epsilon$ позитивним зрушенням, яке покращує добробут людини більше, ніж інші засоби зміни політичних обставин, такі як голосування на виборах. Коли постає питання - витратити роки свого життя для зміни політики чи переїхати, перший варіант багатьом особам видається непевним («інвестицією 3 низькою та віддаленою потенційною віддачею»), i таким, що навряд чи матиме якийсь ефект, а другий - тим, що гарантовано дозволить змінити життя на краще $[18 ; 19]$. Аргументація Іллі Соміна на користь переваг «foot voting» (щодо міжнародної міграції, вибору місця проживання в межах однієї країни - на прикладі федеральної системи США, а також прийняття рішень у приватному секторі) спирається на гіпотезу, висловлену Чарльзом Тібу в статті «Чиста теорія локальних витрат» (1956) про можливість для підвищення ефективності пропозиції суспільних благ у цілому використовувати міграції як механізм розкриття (виявлення та агрегування) вподобань споживачів стосовно локальних суспільних благ (послуг та податкових ставок) - в умовах бюджетної децентралізації та за наявності достатньої кількості різноманітних місцевих громад, муніципалітетів, регіонів.

Висновки i перспективи подальших досліджень. Міграційна активність українців викликає занепокоєння у вітчизняних дослідників та небайдужих громадян. Її природність та корисність (як для безпосередніх учасників, так і для країни походження) - не визнається цими дбайливцями державних інтересів, бо не вписується в їхні уявлення про економіку (як стаціонарну) та узвичаєний спосіб життя. Попри це, численні учасники міграцій, завдяки ринковому ціновому механізму та іншим інструментам, пов'язаним 3 економічною свободою, спираючись на знання власних обставин та ресурсів, вишукуючи сприятливі можливості й перетворюючи їх на підприємницькі рішення, доводять 
свою здатність бути «the masters of their fate», реалізують свій творчий потенціал й підвищують загальний рівень добробуту.

Міграційна активність потребує аналізу з позицій динамічного розуміння ринкових процесів, у термінах індивідуальної поведінки. Йдеться про «вибір», основу якого складають «суб'єктивна цінність», «пошук нових можливостей для отримання прибутку», «здатність створювати та виявляти нові цілі й засоби», «невизначеність»; проявами якого є «наміри» та «дії», орієнтирами - ринкові ціни, а середовищем - система поділу праці з властивими їй ефектами та кореляціями (закономірностями руху робочої сили, товарів, капіталу).

Перспективи подальших студій убачаємо насамперед в деталізованому описі спонтанного процесу координації міграцій, здійснюваного за допомогою ринкового цінового механізму, та - контекстуалізації можливостей використання теорії порівняльних переваг при вивченні міграційної активності.

\section{Лimepamypa:}

1. Мизес Л. Человеческая деятельность: Трактат по экономической теории. М.: Экономика, 2000. 878 c. URL: http://www.libertarium.ru/humanact

2. Мизес Л. Либерализм в классической традиции / пер. с англ. М.: Социум, 2001. 239 с.

3. Міграція як чинник розвитку в Україні. Дослідження фінансових надходжень, пов’язаних з міграцією, та їхнього впливу на розвиток в Україні / Міжнародна організація з міграції (МОМ), Представництво в Україні. К., 2016. URL: https://www.iom.org.ua/sites/default/files/mom_migraciya_yak_chynnyk_ rozvytku_v_ukrayini.pdf.

4. Еміграція висококваліфікованих кадрів $є$ корисною для України. URL: https://platfor.ma/society/4e723d2a4601f/.

5. Міфи і факти про українську трудову міграцію до країн Вишеграду: довідник. Керівник проекту: Ірина Сушко, ГО «Європа без кордонів». URL: https://www.slideshare.net/EWBUkraine/ss-147973708.

6. Rothbard, M. N. (2007) Introduction to Natural Law. URL: https://mises.org/library/introduction-natural-law.

7. Olsaretti, S. Liberty, Desert and the Market. Cambridge University Press. 2004. 184 p.

8. Хайек Ф. А. Пагубная самонадеянность. Ошибки социализма / пер. 3 англ. М.: Новости, 1992. 304 с.

9. Хейне П. Экономический образ мышления / пер. с англ. М.: Каталаксия, 1997. 704 c. URL: http://www.libertarium.ru/lib_thinking.

10. Portes, J. (2019) The Economics of Migration. URL: https://journals.sagepub.com/doi/full/10.1177/1536504219854712.

11. Гайдуцький А. Міграційний клондайк для України. URL: https://zn.ua/ukr/international/migraciyniy-klondayk-dlya-ukrayini-ukrayina-mozhevp-yatero-zbilshiti-groshovi-perekazi-migrantiv-yakscho-skoristayetsya-dosvidomfilippin-_.html.

12. Кирцнер И. Конкуренция и предпринимательство / пер. с англ. под ред. проф. А. Н. Романова. М.: ЮНИТИ-ДАНА, 2001. 239 с. URL: http://www.libertarium.ru/lib_competition_02. 
13. Soto de, J. U. (2018) Four Hundred Years of Dynamic Efficiency. URL: https://mises.org/library/four-hundred-years-dynamic-efficiency.

14. Newman V. Уничтожение калькуляционного аргумента с помощью фактов и логики. URL: https://medium.com/libertarian-state/-уничтожениекалькуляционного-аргумента-с-помощью-фактов-и-логики-с929e0aa91d9.

15. Deist, J. Immigration Roundtable: Murray Rothbard. URL: https://mises.org/library/immigration-roundtable-murray-rothbard.

16. Ebeling, R. (1995) Free Trade, Managed Trade, and the State. URL: http://www.amatecon.com/etext/cftoi/cftoi-ch02.html.

17. Deist, J. (2018) Immigration Roundtable: Walter Block. URL: https://mises.org/library/immigration-roundtable-walter-block.

18. Somin, Ilya. Free to Move: Foot Voting, Migration, and Political Freedom, Oxford University Press, 2020. 272 p.

19. Nowrasteh, A. (2020) Free to Move: Foot Voting, Migration, and Political Freedom. URL: https://www.cato.org/cato-journal/fall-2020/free-move-footvoting-migration-political-freedom?queryID=9022a02900d5e20a15807127c71fd3dc.

\section{References:}

1. Mizes L. Chelovecheskaja dejateljnostj: Traktat po ekonomicheskoj teorii. M.: Ekonomika, 2000. 878 s. URL: http://www.libertarium.ru/humanact

2. Mizes L. fon. Liberalizm $\mathrm{v}$ klassicheskoj tradicii / per. s anghl. M.: Socium, 2001. $239 \mathrm{~s}$.

3. Mighracija jak chynnyk rozvytku v Ukrajini. Doslidzhennja finansovykh nadkhodzhenj, pov'jazanykh $\mathrm{z}$ mighracijeju, ta jikhnjogho vplyvu na rozvytok $\mathrm{v}$ Ukrajini / Mizhnarodna orghanizacija z mighraciji (MOM), Predstavnyctvo v Ukrajini. K., 2016. URL:https://www.iom.org.ua/sites/default/files/mom_migraciya_yak_chynn yk_rozvytku_v_ukrayini.pdf.

4. Emighracija vysokokvalifikovanykh kadriv je korysnoju dlja Ukrajiny. URL: https://platfor.ma/society/4e723d2a4601f/.

5. Mify i fakty pro ukrajinsjku trudovu mighraciju do krajin Vysheghradu: dovidnyk. Kerivnyk proektu: Iryna Sushko, GhO «Jevropa bez kordoniv». URL: https://www.slideshare.net/EWBUkraine/ss-147973708.

6. Rothbard, M. N. (2007) Introduction to Natural Law. URL: https://mises.org/library/introduction-natural-law.

7. Olsaretti, S. Liberty, Desert and the Market. Cambridge University Press. 2004. 184 p.

8. Khaj'ek F. A. Paghubnaja samonadejannostj. Oshibki socializma / per. z anghl. M.: Novosty, 1992. 304 s.

9. Khejne P. Ekonomycheskij obraz myshlenija. Per. $\mathrm{s}$ anghl. M.: Katalaksija, 1997. 704 s. URL: http://www.libertarium.ru/lib_thinking

10. Portes, J. (2019) The Economics of Migration. URL: https://journals.sagepub.com/doi/full/10.1177/1536504219854712.

11. Ghajducjkyj A. Mighracijnyj klondajk dlja Ukrajiny. URL: https://zn.ua/ukr/international/migraciyniy-klondayk-dlya-ukrayini-ukrayina-mozhevp-yatero-zbilshiti-groshovi-perekazi-migrantiv-yakscho-skoristayetsya-dosvidomfilippin-_.html. 
12. Kircner Y. Konkurencija i predprynimateljstvo / per. s anghl. pod red. prof. A. N. Romanova. M.: JuNYTY-DANA, 2001. 239 s. URL: http://www.libertarium.ru/lib_competition_02.

13. Soto de, J. U. (2018) Four Hundred Years of Dynamic Efficiency. URL: https://mises.org/library/four-hundred-years-dynamic-efficiency.

14. Newman V. Unischtozhenye kaljkuljacionnogho arghumenta $\mathrm{s}$ pomoshhjju faktov i loghiki. URL: https://medium.com/libertarian-state/unychtozhenye-kaljkuljacyonnogho-arghumenta-s-pomoshhjju-faktov-y-loghykyc929e0aa91d9.

15. Deist, J. Immigration Roundtable: Murray Rothbard. URL: https://mises.org/library/immigration-roundtable-murray-rothbard

16. Ebeling, R. (1995) Free Trade, Managed Trade, and the State. URL: http://www.amatecon.com/etext/cftoi/cftoi-ch02.html.

17. Deist, J. (2018) Immigration Roundtable: Walter Block. URL: https://mises.org/library/immigration-roundtable-walter-block.

18. Somin, Ilya. Free to Move: Foot Voting, Migration, and Political Freedom, Oxford University Press, 2020. 272 p.

19. Nowrasteh, A. (2020) Free to Move: Foot Voting, Migration, and Political Freedom. URL: https://www.cato.org/cato-journal/fall-2020/free-move-footvoting-migration-political-freedom?queryID=9022a02900d5e $20 \mathrm{a} 15807127 \mathrm{c} 71 \mathrm{fd} 3 \mathrm{dc}$

The article outlines the space of opportunities created by migration for an individual. The opportunities are an integral part of an active choice as a basic attribute of a human behavior. People have the ability to choose because they can discover the causal relationships that determine the processes of change, to seek new opportunities, to set goals, to find the most appropriate means to achieve them. Acting in their own interests, people create choices for others.

In the studies on the international migration of Ukrainians, most local scholars deny the benefits of internationalizing the labor market and advocate stereotypes of demographic alarmism; they interpret migrations from the standpoint of holism, essentialism, statism, and interventionism. With such a perception, migration takes the form of a painful social problem that needs to be solved immediately; its consequences are described as mostly negative. The media coverage of Ukrainian migration is quite politicized.

This politicization is aimed to disorient millions of ordinary citizens, devalue their personal choices, deprive them of opportunities, curb individual initiative and competition, push the government to impose restrictive measures, and undermine the Ukraine's course toward European integration and sociocultural modernization.

The freedom of movement, the right to free choice of residence and the nature of activities were justified within the theories of natural law and utilitarianism. The current economic rationale for the resourcefulness of migration is the same as for markets. Politically, freedom of movement, the ability to choose a place to live and work is one of the fundamental values of the united Europe, one foundation of the EU.

The decision on spatial mobility is the choice based on the category of "values". The situation of choice gives an idea of the coordinate system, which is not that much 
connecting goals and means, but involves a persistent search for favorable opportunities. It bases such a search on the assimilation of the experience of the past and the tension of imagination to discover and build the future through activity. Migration is the act of individuals, a social phenomenon which needs to be explained in the logic of individual behavior.

An adequate assessment of the resourcefulness of specific acts of spatial mobility is possible only in the context of discovery and subjective perception of their participants, the ability to achieve certain goals, in implementing appropriate actions and to take advantage of opportunities. Such an assessment should consider the correlations and effects inherent in the system of labor division within which migrants operate. Migrations are part of the division of labor system.

The market coordinates them through prices. In this case, the existing inconsistency manifests itself as a favorable opportunity. Responding to which, it triggers a spontaneous process of coordination, which requires constant adaptation of economic agents to new conditions and a search for new opportunities.

УДК 338.47

DOI: $10.35340 / 2308-104 X .2020 .89-4-10$

\author{
ДОСЛІДЖЕННЯ РОЗВИТКУ \\ ТРАНСПОРТНОЇ ГАЛУЗІ \\ УКРАЇНИ: СУЧАСНІ \\ ТЕНДЕНЦІЇ ТА ПЕРСПЕКТИВИ
}

ГАЛЬКЕВИЧ М. В.,

кандидат економічних наук, старший викладач, Кілійський транспортний фаховий коледж Державного університету інфраструктури та технологій

\section{RESEARCH OF DEVELOPMENT OF THE TRANSPORT INDUSTRY OF UKRAINE: MODERN TRENDS AND PROSPECTS}

\author{
HALKEVYCH M., \\ PhD in Economics, Lecturer, \\ Kiliya Transport Professional \\ College of State University of \\ Infrastructure and Technologies
}

Визначено роль транспортної галузі в розвитку національної економіки. Досліджено особливості розвитку транспортної галузі України та виокремлено проблеми в иій сфері. Сформовано основні перспективні напрями державної політики, спрямовані на розвиток транспортної галузі та повноцінне використання ї̈ потенціалу для сочіально-економічного розвитку краӥни.

Ключові слова: транспорт; транспортна галузь; ефективність; розвиток.

Определена роль транспортной отрасли в развитии национальной экономики. Исследованы особенности развития транспортной отрасли Украины и выделены проблемы в этой сфере. Сформированы основные перспективные направления государственной политики, направленные на 